\title{
8 The Medicine Supply System of the Qing Court
}

\author{
Xueling Guan
}

\begin{abstract}
To secure the supply of medicinal products for the Qing palace, the court took a series of measures to mobilize several institutions to participate in the operation. The operation resulted in a comprehensive, flexible, and multivariate supply system. Although many offices were involved in the system, all of them were under imperial control. The central government's strong vertical control over the regional societies facilitated the smooth operation of the system. The collaboration of various institutions ensured the functioning of medicinal projects for the Qing court.
\end{abstract}

Keywords: medicinal products, supply, court, Qing dynasty

During the Qing dynasty, pharmacotherapy - the consumption of prepared medicines - was the main form of medical intervention used in the imperial court. ${ }^{1}$ To ensure the uninterrupted supply of the best medical materials for the benefit of the emperor's health, an entire medicine supply chain was established, mobilizing a host of institutions from the local to the central to participate in the processes of collection, procurement, preparation, dispensation, and disposal of medicinal ingredients and products. This chapter investigates the operations of this supply system and infers from it the Qing court's conceptions and attitudes towards materiality, efficacy, and profitability. Since both the imperial body and the medicinal substances administering to it were living entities, they were both in a state of flux and equally liable to decay. Thus, in order to harmonize the

1 The term 'medicine' in this article refers to Chinese medicinal ingredients, Chinese readymade medicine, and Western medicines.

Siebert, Martina, Kai Jun Chen, and Dorothy Ko (eds), Making the Palace Machine Work: Mobilizing People, Objects, and Nature in the Qing Empire. Amsterdam, Amsterdam University Press 2021 DOI: 10.5117/9789463720359_CHo8 
two vulnerable systems of bodies and medicines, the supply chain and its attendant accounting system needed to function with regularity and flexibility - as a reliable, predictable machine on the one hand which, on the other hand, could be adjusted to changing situations by ad hoc tinkering as required.

\section{Collecting Medicinal Stuff: The Local Tributes}

Traditional Chinese medicine put special value on the place-based authenticity or au terroir quality (daodi 道地) of medical materials. Tributary medical substances not only indicated imperial control of these regions, but also symbolically flaunted it. It was believed that only habitats of certain regions could produce the best kinds of medical materials, thereby determining the quality of the manufactured medicine, and eventually affecting its healing capability. The Qing dynasty continued its predecessor's practice of requiring local tributes from disparate corners of the empire, to ensure the supply of high-quality medicines for the court. As stated in the Collected Statutes of the Ming (Ming huidian 會典), 'all the provinces [have to] submit their annual collection in the original form of medicinal materials (bense本色) together with the converted silver cash (zhese 折色). ${ }^{2}$

This statute carried several messages: firstly, the provinces that produced medical materials were obliged to render them to the court as local tributes. This guaranteed the variety and au terroir authenticity of medicines. Secondly, the medicines could be rendered to the court in two alternative forms: in their 'original form' (bense) - as the medical material itself - or in a 'substitute form' (zhese), that is, the silver cash converted from the value of medical materials. Thirdly, the statute makes evident that, whereas each province had a fixed tribute quota, if the quota of medical materials could not be fulfilled due to poor harvest or other reasons, the shortfall had to be paid for in the substitute form of silver cash. This silver would then be used to purchase the materials that the Imperial Dispensary (Yuyao fang 御藥房) needed from the market. This system, with an internal backup measurement (or dual intake tracks), was designed to maximize supply, quality and flexibility by supplementing the age-old tribute system with market mechanisms. The former afforded regularity whereas the latter

2 Da Qing huidian (Yongzheng ban) 大清會典 (雍正版), eds. Yunlu 允祿 et al., juan 248, in Jindai Zhongguo shiliao congkan sanbian 近代中國史料叢刊三編 (Taipei: Wenhai chubanshe, 1985), vol. 790, 15731 . 
provided flexibility. The subliminal message seems to be that the emperor's health was everybody's business.

Renhe County 仁和縣 in Zhejiang Province was one of the empire's major producing areas for herbal medicinal materials. Its county gazetteer, printed in 1687 , provides a detailed summary of the actual data showing how the local administration implemented the state tribute quotas between the 2nd year of Shunzhi (1645) and the 13th year of Kangxi (1674), i.e. in the early years of the Qing dynasty. ${ }^{3}$ For instance, in 1645 , the amount of submitted medicinal materials that was converted into silver cash reached twentyseven percent. In the following year, the entire annual tribute was collected in the form of silver cash. Then in 1647 , the collected medicinal materials consisted of the following substances: gold leaf, silver leaf, maimendong (麥門冬, Ophiopogon root, which soothes the stomach), xusuizi (續隨子, caper seeds, a cathartic medicine), qianjincao (千金草, Fortune Eupatorium herb, which cures heatstroke), xiangbaizhi (香白芷, Dahurian Angelica root, which cures headache and toothache), Chinese chestnut shell (li ke 栗壳, which calms nausea and coughing), and mituoseng (密陀僧, the oxidized lead ore litharge, which alleviates sores, eczema, and ulcers). Some of the products did not actually originate from Renhe but were imported from Wuhu 無湖, about 280 kilometres away from Renhe. In general, the court collected medical materials from their original habitats. But as time went on and some materials no longer grew in those areas, the court still maintained the previous rules and kept assigning a quota to them. In order to fulfil these quota, local officials would collect money from the community and purchase the respective medical materials from the habitats they were still available in.

The situations in 1648 and 1649 were the same as in 1646 , when the entire tributes were converted into silver cash. The total amount of cash - including delivery expenses - was 68 liang (taels), 6 qian, and 4 fen. Between 1653 and 1661, both the assortment of materials collected and the amount of cash paid remained consistent. For those years the gazetteer also gives the weight of each collected medicinal: 64 catties (jin 斤) of baizhu (白术, the root of white Atractylodes), 50 catties of maimendong, 500 sheets (tie 貼) of gold leaf, 100 catties of xiangbaizhi, 50 catties of qianjincao, and 20 catties of xusuizi - all

3 Zhao Shi'an 趙世安 (Qing) et al., Renhe xianzhi 仁和縣志, 28 juan, printed in the 26 th year of Kangxi reign (1687) (rep. in Zhongguo difangzhi jicheng: Zhejiang fuxianzhiji 中國地 方志集成: 浙江府縣志輯, vol. 5), juan 6: tu gong土貢 (local tributes), 28b-31a. See also the digital copy at Harvard-Yenching Library: http://nrs.harvard.edu/urn-3:FHCL:14361176, accessed September 2020. 
considerable amounts. The value of the materials paid in substitute cash was in total 37.11 taels. Delivery expenses had to be added to both: for the medicinal materials this amounted to 3.89 taels, and for the cash to 13.98 taels of silver. In the first two years of the Kangxi reign (1662-63) the same amounts of medicinal and silver are listed. From the third to the 6th year of Kangxi (1664-67), all of the medicines were again collected in the 'converted form' (zhese); in 1668 some were delivered in the original form, others in the substitute form. Medical materials delivered in their original form included 60 catties of baizhu, $5^{\circ}$ catties of maimendong and $5^{\circ}$ sheets of gold leaf, while the equivalent of 50 catties of qianjincao, 20 catties of xusuizi, was paid in the substitute silver cash. Of xiangbaizhi $5^{0}$ catties were delivered in their original form and the equivalent of 50 catties in substitute form.

From 1669 to 1674 all the medicinal materials were delivered in both forms, in kind and as substitute cash in a ratio of roughly one to two. Thus, 22 catties of baizhu were delivered in kind and 43 in cash. For xiangbaizhi the numbers were 33 and 66 catties, for maimendong 16 and 33, for xusuizi six and 13, for gold leaf 16 and 30 sheets. The delivery expenses followed this ratio: for in-kind material it amounted to 1.21 catties and for cash to 2.67 catties (see Table 8.1).

Table 8.1 Annual tribute of medicinal material from Renhe County

\begin{tabular}{|c|c|c|c|c|}
\hline \multirow[t]{2}{*}{ Year(s) } & \multicolumn{2}{|c|}{ Original form } & \multicolumn{2}{|c|}{ Converted form } \\
\hline & Medical materials & Quantity & Medical materials & Quantity/Value \\
\hline \multirow{6}{*}{ 1653-1661 } & baizhu & 64 catties & & \multirow{6}{*}{37,11 taels silver } \\
\hline & maimendong & 50 catties & & \\
\hline & xiangbaizhi & 100 catties & & \\
\hline & xusuizi & 20 catties & & \\
\hline & qianjincao & 50 catties & & \\
\hline & gold leaf & 500 sheets & & \\
\hline \multirow{4}{*}{1668} & baizu & 60 catties & qianjincao & 50 catties \\
\hline & maimendong & 50 catties & xusuizi & 20 catties \\
\hline & xiangbaizhi & 50 catties & xiangbaizhi & 50 catties \\
\hline & gold leaf & 50 sheets & & \\
\hline \multirow{6}{*}{ 1669-1674 } & baizhu & 22 catties & baizhu & 43 catties \\
\hline & maimendong & 16 catties & maimendong & 33 catties \\
\hline & xiangbaizhi & 33 catties & xiangbaizhi & 66 catties \\
\hline & xusuizi & 6 catties & xusuizi & 13 catties \\
\hline & gold leaf & 16 sheets & qianjincao & 50 catties \\
\hline & & & gold leaf & 30 sheets \\
\hline
\end{tabular}

Source: Zhao, Renhexianzhi, juan 6, 28b-31a 
In the period from the 4th year of the Kangxi era (1665) until the compilation of the Renhe gazetteer report twenty-two years later, the actual tribute of these medicinal materials including delivery expenses was reduced to 21.32 taels in silver. The alternation between the two tracks for collecting medicine within twenty-nine years in early Qing reveal flexibility and adaptability as an important aspect of the transforming palace machine.

Once collected, the transport of these tributary medicines also required careful management. After the prefectures and counties levied medical materials from their people, the materials and substitute cash had to be delivered to the designated central agency in the capital. The Qing statutes stipulated that 'as was codified at the beginning of the Shunzi reign, for all deliveries of original kinds of materials and substitute cash sent by the provinces the regional guardian (shoudao 守道) and provincial administrative commissioner (buzhengsi 布政司) shall assign honest and efficient officers (lian gan 廉干) to file and examine the documents, and dispatch labour for water and land transportation in order to deliver the materials to the capital before the deadline date'. ${ }^{4}$ The attention paid to time management and the conflation of officials' moral quality and managerial skills are extremely similar to the case of the Gao-pu jade transport analysed in Chapter Six.

Upon arriving at the capital, the handover and inspection also had to follow a fixed procedure. The materials were first delivered to the Medicinal Material Warehouse (Shengyao ku 生藥庫) of the Imperial Academy of Medicine (Taiyiyuan 太醫院). The officials in the warehouse would inspect the quality of the delivered materials, count the quantities, and note the results down in documents. The warehouse was only responsible for evaluating and - in early Qing times - also for safekeeping the medical materials; it had no executive power over their use. That responsibility lay with the Board of Rites (Libu 禮部), which granted the reception and consumption of medical materials. From the 3rd year of Kangxi (1664) onwards a third institution became involved in the administration of medical materials. Due to administrative changes the materials were no longer stored in the Imperial Academy of Medicine, but in the Board of Revenue (Hubu 户部). Nevertheless, power over their delivery was still held by the Board of Rites. Thus, when the Imperial Dispensary needed any medical raw materials, the Imperial Academy of Medicine needed to file an application to the Board of Rites, which in turn would forward the request to the Board of Revenue, whereupon the materials could be picked up from the Medicinal Material 
Warehouse. ${ }^{5}$ This collaboration between departments from both the inner court and the civil government mirrored the border-crossing trajectory of the medical substances.

\section{Harnessing the Market: Medicine Merchants and the Court}

Connecting the palace machine to the market mechanism, some of the medical materials needed by the court were purchased by commissioners, a job entrusted to prominent medicine merchants. According to the archives examined so far, the main medicine merchants or shops commissioned were the Wanquan House (Wanquan tang 萬全堂) and Tongren House (Tongren tang 同仁堂) in Beijing. ${ }^{6}$ This arrangement followed a proposal by Liu Shengfang 劉聲芳, director of the Imperial Academy of Medicine, who stipulated that, from the 2nd month of the 1st year of the Yongzheng reign onwards (March 1723), Wanquan House and Tongren House should be in charge of purchasing medical materials, on an annually rotating basis in which each shop would be exclusively responsible for one year. In contrast to the tributary medicinal materials, these purchased items did not have to be inspected by the Imperial Academy of Medicine, but were delivered directly to the Imperial Household Department (Neiwufu 內務府), to be inspected and received by the Department's director. The Wanquan House or Tongren House was required to initially provide the medicinal materials at their own expense. Then, in the 8th month of each year, the Imperial Dispensary would report its actual yearly usage of medicines, in names and quantities, to the Imperial Academy of Medicine, which, together with the Ministry of Revenue, would inspect and review the market price of the medical materials, to then finally issue corresponding payments to the relevant merchant. In the gth year of Yongzheng (1731), Lin Zucheng 林祖成, vice director of the Imperial Academy of Medicine, proposed setting the price permanently, in line with its market price in the year 1731, no matter how the market price might change in the future. ${ }^{7}$ His proposal became an established rule for commissioned

5 Da Qing huidian shili (Guangxu ban) 大清會典事例 (光緒版), ed. by Kungang 崑岡 et al., 1899 (Beijing: Zhonghua shuju, reprint 1991), vol. 1105, 10.

6 After the middle of Qianlong's reign, Tongren House became the only merchant commissioned to purchase medicines for the court.

7 Zou'an 奏案, no. 05-0032-006, 'Caiban yaowei zhi weiyuan Yue Fengming deng cheng wei wu li dianban qing jietang banli yi an 采辦藥味之委員樂鳳鳴等呈為無力垫辦請借帑辦理一案 (On the case of medicine commissioners such as Yue Fengming who were unable to pre-pay for the medicines themselves and have requested an advance payment from the court)', QL 4/10/3 
purchases for a long time subsequently. For the merchants this meant not only having to deliver the materials first and receive payment later, they also lost any influence over the pricing but had to take whatever was dictated as being the current price by the administrative unit; for any adjustments to the rising market price, they had to submit a request to the emperor himself, who would then decide whether or not to permit any price increase in their invoice.

The rules and procedures established to interlink the palace machine's cogs with the merchants' world were time and time again challenged by obstacles arising from the rules themselves and from the needs of the time. As the example above has shown, the rules were conceived to the detriment of the merchants. Being required to pay in advance for imperial purchases - a de facto no-interest loan to the emperor - created a capital crunch for the medicine houses. Especially when a natural disaster or epidemic drove up the prices of medicines, the merchants would suffer financial loss. Furthermore, since the payment to merchants was not based on the current market price, but in line with an artificial price set years earlier, the merchants were effectively made to shoulder the risks of price fluctuations by themselves. Maintaining an adequate supply of capital to navigate these uncertainties became one of the merchants' heaviest burdens. Therefore, on many occasions the merchants of Tongren House asked for adjustments to the standard procedures. They either petitioned to be relieved of their commission job, requested advance payments, or asked to be allowed to increase the set prices on their invoices. ${ }^{8}$ Motivated in part by trust in the Tongren House and in part by a desire to maintain a regular supply of medicine for the court, the emperor permitted deviations from his own rule many times, by agreeing to Tongren House's entreaties. During the Yongzheng reign (1723-1736), for example, as much as 40,00o taels of silver was issued as advance payments. ${ }^{9}$ In the gth year of Qianlong (1744) an increase of one-third of the set price was permitted; in addition, in a number of the following years advance payments of 3,000 taels of silver were issued each year. In the 7 th month of the 16 th year of Daoguang (August 1836), the Tongren House received a loan of 1,00o taels of silver from the Bullion Vaults of the Grand Storage Office (Guangchusi Yinku 廣儲司銀庫), under the Imperial Household Department. ${ }^{10}$ In sum, the court archives show that, from the early 18th century to the end of the Qing dynasty in 1912, the Tongren House

\footnotetext{
(3 November 1739). The Zou'an (official memorials submitted to the throne) cited in this chapter are all stored in The First Historical Archives of China, Beijing. The numbers refer to their shelfmarks. 8 Beijing Tongrentang shi 北京同仁堂史, ed. Beijing Tongrentang Group Co., Ltd. et al. (Beijing: Renmin ribao chubanshe, 1993), 22.

9 Zou'an, no. 05-0032-0o6.

10 Beijing Tongrentang shi, 20.
} 
Figure 8.1 Medicinal bottle offered by the Tongren House to the court

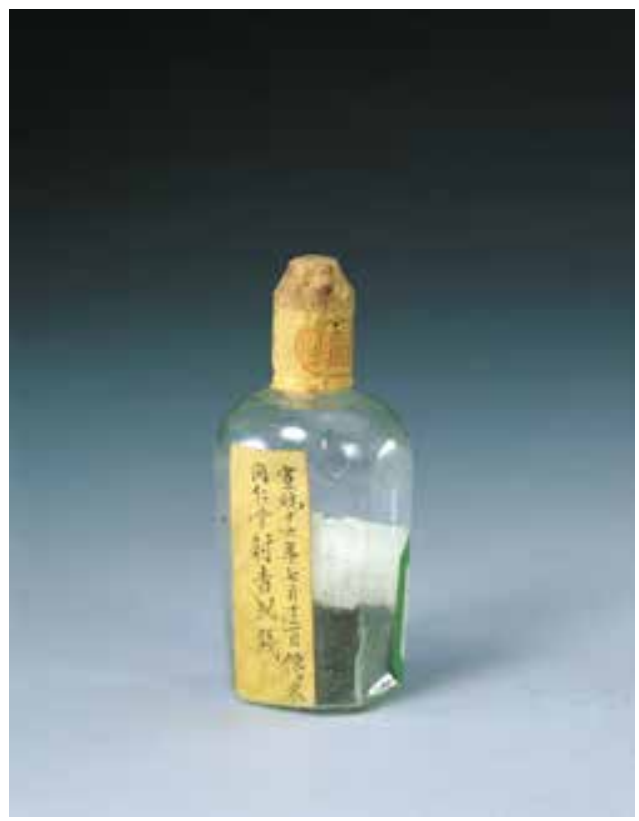

Source: The Palace Museum, Beijing

merchants consistently petitioned for advance payments and price increases, with the emperor usually granting these requests. A complementary and interdependent relationship had evidently been established between the merchants of Tongren House and the Qing imperial court. The court needed Tongren House to purchase the medicinal material through its commercial network and their experts to guarantee the quality of these purchases, whereas the medicine shop capitalized on the prestige thus derived to further develop and gradually attain a monopolistic position in the industry (see Figure 8.1, which shows a bottle containing musk, shexiang 塮香, offered by the Tongren House to the court in the early 2oth century).

\section{Local Production and Court Monopoly: The Case of Donkey-Hide Gelatine}

In parallel to these professional, commercial routes for acquiring medicinal materials, their systematic collection directly from their local sources remained an important activity of the imperial court. Some of these materials never reached the open market - at least not in the same quality - but 
were exclusively produced for the court. Ejiao (阿膠, donkey-hide gelatine from Dong'e county 東阿縣 in Shandong) provides an excellent example of such a local product, which the court safeguarded its exclusive access to. This traditional medicine was made from water and donkey skin, stewed with crystal sugar, yellow rice wine and herbal oil. It was used as a tonic to replenish a person's blood and nourish their yin. The quality of ejiao was highly dependent on two things - the raw materials used, especially the water quality, and the artisans' manufacturing skills. Jean-Baptiste Du Halde (1674-1743) gave an extensive account of the material and production of ejiao in his Description de l'Empire de la Chine. ${ }^{11}$ The water used to make ejiao for the court had unique qualities. It came from a deep well close to the town of Dong'e County. 'Its Water is extremely clear, and more ponderous than common Water; if it be mix'd with foul Water, it refines it instantly, by precipitating the Filth to the Bottom of the Vessel'. ${ }^{12}$ Since this water could filter impurities, the ejiao made from it was very clean. The local government assigned guards to protect and regulate access to the well. In addition, most of the year the well was closed with a seal of the local office, only being opened during the set season of making ejiao for the emperor. Political power ensured exclusive access to natural resources - in this case, the superb water and the best donkey skins. For the other main raw material healthy donkeys with strong muscles and shiny black coats were selected and skinned. Ejiao production was a very complex process with exacting standards. The manufacturing procedure comprised more than ten stages, including choosing and washing the materials, melting the skin, extracting, cutting and shaping, and weathering. The finest materials and artisanship were required to make top-quality ejiao. Hence, the local government directed the best local artisans to focus on making ejiao for the emperor. ${ }^{13}$

\section{Storage and Recycling: When Medicine Became Stale}

The data from Renhe county above have shown the large body of medicinal materials that the Qing court acquired every year via the tribute system. As

11 Du Halde's source of information on ejiao (Ngo-kyau) was a letter which Pater Parennin sent from Beijing, together with the actual ingredients, to the French Academy of Sciences in May 1723. See Lettres édifiantes et curieuses écrites des missions étrangères (Toulouse: Sens et Gaude, 1811), vol. 19: 'Memoire de la Chine', 242-261, here 253-254.

12 Jean-Baptiste Du Halde, Description of the Empire of China and Chinese-Tartary (trans. from the French, London: J. Watts, 1741), vol. 2, 230.

13 Lettre edifiante et curieuses, vol. 19, 242-261. 
the efficacy of medicinal materials perishes over time, dealing with stale or out-of-date drugs was a standard issue faced by the Imperial Dispensary. The historical documents show that the Qing court adopted different approaches to deal with medicinals in various conditions. For instance, in the leap month after the 6th month of the 5 th year of Qianlong (July/August 1740), the Imperial Dispensary checked the stored medical materials and found that fifty-three kinds had already been stored for a long period of time and had become stale. Thirty-five kinds of these out-of-date medicines were considered still usable, including cinnabar (zhusha 朱砂), orpiment (cihuang 雌黄) and ginseng cream. Of the other eighteen kinds some had become infested by worms so were unusable while for others - for example toluene (duoermendina 多而門第納) sourced from Western countries, root of silverweed cinquefoil (yanshouguo 延壽果) and wannianjian (萬年劍, identification unclear) - the doctors were no longer knowledgeable about their uses and effects. ${ }^{14}$ Prince Hongzhou 弘昼, who was in charge of the Imperial Dispensary at that time, proposed that the medicines that were considered still usable should immediately be delivered to the Imperial Dispensary and that new ones would only be allowed to be distributed after those old ones had been used up. This suggestion evinced an awareness that can be described as conservationist and ecological, encapsulated in the Chinese saying, 'extracting the maximum use from a material' (wu jin qi yong 物盡其用). He ordered that the worm-damaged medicines and those of unknown usage should be disposed of immediately. Prince Hongzhou further demanded strict compliance with the rule that, for any unfamiliar medicines that entered the storage from then on, the Imperial Dispensary was responsible for inquiring about their usages and effects and keeping a record of these for future reference. ${ }^{15}$

Regularly checking the storage was actually an established routine for the Imperial Dispensary (see also the vignette essay introducing part three of this volume). Nevertheless, many more cases like this are documented in

14 The phenomenon of medicines with unknown effects and usage in the court store rooms mainly applied to materials from foreign countries or vassal states. When arriving at the palace as a gift or tribute, Western missionaries and doctors from the Imperial Academy of Medicine were assigned to examine them and the Imperial Dispensary was asked to note down the main effects in their records and stick yellow tags with the names onto the medicines' packaging. But over time, these documents got lost and therefore people no longer knew what ailments these medicines could be used to treat.

15 Zou'an, no. 05-0038-023: 'Heqinwang zouwei Yaofang tianshe zhushi deng wutiao shi 和亲 王奏為藥房添設主事等五條事 (Prince Heqin requesting the Imperial Dispensary to add the position of a secretary and other together five issues)', QL 5/r6/13 (5 August 1740). 
the archival materials, including the following example. In the 1oth month of the 28th year of Qianlong (November 1763), the Imperial Dispensary detected forty-one kinds of outdated medicines in storage. Again they were categorized into three groups: those 'stored for years but with no known usages or effects', those which 'might be still usable', and those 'mildewed, rotten and no longer applicable'. For those of the last group, namely Cordyceps sinensis (dongchong xiacao 冬蟲夏草) and silverweed cinquefoil (yanshouguo), the office asked for approval and, only after the emperor had agreed, disposed of them. Among those considered 'still usable', fourteen kinds were kept for future use, but the rest was sent to the Chongwen Gate 崇文門 Tax Bureau to set a price for them and then handed over to the Tongren House merchant Zhang Shiji 張世基 as a trade-in for other medical materials.

In this shrewd exchange, no doubt facilitated by imperial power, old stock was effectively deployed as payment for new purchases. The Qianlong emperor ruled that, 'hereafter all the medical materials coming to the court from the outside, except for a reasonable amount that needs to be kept as a reserve for use by the court, the rest should be constantly accounted for [possibly to serve as a trade-in]. ${ }^{16}$ This shows the mercantilist mindset of the Qing court, whereby whatever was not consumed or kept in reserve should be traded back to the market while still fresh enough. Accurate reckoning and control of the movement of medicinal materials in and out of the court was key to maximizing profit. Later on, in the 4th month of Qianlong's 4oth year (May 1775), the rule was extended to 'those medical materials collected and stored that are never actually used or which have only few potencies'. Again, the Chongwen Gate Tax Bureau fixed a price, for which it was handed over to Zhang Shiji to sell, and the expected profit was traded in for other medical materials currently needed by the court. ${ }^{17}$

In addition to Chinese medicines, numerous Western medical materials poured into the Qing court, especially during the reigns of the Kangxi, Yongzheng, and Qianlong emperors. The Dew Room (Lufang 露房) in Wuying Palace (Wuying dian 武英殿), a small storage room originally used for perfumes, was the main locale for storing these Western medicines in the Qing court, even though they were seldom used. When staff were sent to check the store room in the summer of the 19th year of Jiaqing (1814), in preparation for renovating

16 ‘嗣後凡有外進各項藥味內酌量存留備用外, 其餘隨時酌量奏明, 照此辦理'. See Qinding Zongguan Neiwufu zeli er zhong 欽定總管內務府則例二種, rep. in Gugong zhenben congkan 故宮珍本叢刊 (Haikou: Hainan chubanshe, 200o), vol. 306, 379-380.

17 Ibid. 
the Dew Room, they found that '[the room] was crammed with bottles full of cloves (dingxiang 丁香), nutmegs (doukou 豆冦), cinnabar oil (rouguiyou 肉桂油), etc. The oil has thickened into a paste-like substance, so hard that even a spoon cannot scoop it out'. ${ }^{18}$ This finding shows that the Western materials had been left untouched there for a very long time. Even though they had lost all their medical properties, these materials were still valued as a curiosity. In the end, the Jiaqing emperor gave some of these materials to selected officials, and handed the rest over to the Imperial Workshops. ${ }^{19}$

As already mentioned, the Qing court had a system for collecting new and fresh medicinal materials and disposing of unused or stale and out-of-date ones - ideally by exchanging them for new materials. This promotion of movement and circulation of medical material by way of 'dispensing with the old to make way for the new', can be said to be the working principle of the court's drug management. Although the ways of treating aged materials varied from case to case and each decision had to await imperial approval, there were generally three options: either be economical and keep what was still usable for immediate use and dispose of what had gone off; trade in aging medicinal materials for fresh ingredients via professional merchants; or rededicate them as gifts to officials.

\section{Making Medicine in the Palace Workshops}

The Imperial Dispensary, as one of the offices having specialists responsible for making medicine, was ordered to collaborate with the labour force in several other related departments in the palace machine. This collaboration was not only a form of shared expertise but also a protection mechanism to prevent mistakes. In the case of donkey-skin gelatine outlined above, local manufacturing was needed to take advantage of the freshness of raw materials, the exceptional quality of the locale's spring water, and the specialist skills of artisans in Dong'e county. In many other cases, ingredients were assembled from various parts of the empire to be processed within the palace compound by the Imperial Dispensary and the Imperial Workshops into consumables in the form of balls, powders, creams, and pills.

The Imperial Dispensary was in charge of manufacturing and processing medicines in the court. Since its establishment in the 1oth year of Shunzhi

18 Yao Yuanzhi 姚元之 (1783-1852), Zhuyeting zaji 竹葉亭雜記 (rep. Beijing: Zhonghua shuju, 1982), vol. 1, 21.

19 Ibid. 
(1653), the Imperial Dispensary's major responsibilities had always included maintaining the supply and overall management of concocting medicines for the court. The job of actually making the medicine was undertaken by so-called grinding artisans (nianyao sula 碾藥蘇拉) and compounding doctors (heyao yisheng 合藥醫生), some of whom were recruited from the common people rather than the court elite. The medical officers at the Imperial Academy of Medicine participated in the processes as well. According to the chapter concerning the Imperial Dispensary in the Current Regulations and Precedents from the Imperial Household Department (Zongguan Neiwufu xianxing zeli: Yuyaofang 總管內務府現行則例: 御藥房), 'for all the processing and compounding works for balls, powders, creams and pills in the Imperial Dispensary, the Imperial Academy of Medicine is required to assign medical officers to collaborate with our own officers to supervise the works. ${ }^{20}$ In other words, in a system of mutual control and support, officials from the Imperial Dispensary and the Imperial Academy of Medicine would in all cases co-supervise the manufacturing processes of medicines together. This rule was proposed and then permitted in the 6th

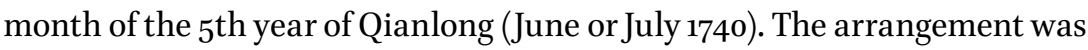
made to prevent mistakes, but it also demonstrates the meticulousness and prudence of the imperial court towards the making of imperial medicine. Liquid medicine was no exception to this rule. To prepare liquid medicines for the use of the emperor and the empress, that process was similarly put under the supervision of both institutions, but the Imperial Dispensary would send a eunuch to function as cooperating partner to the imperial doctor from the Imperial Academy of Medicine. Two servings of medicine were produced from each decocting process. They were cooked as one but then placed into two separate vessels. The medicine decoction from one vessel would be tested first by the imperial doctor from the Imperial Academy of Medicine and then by the imperial eunuch sent by the Dispensary. If no negative effect was detected, the other vessel would be presented to the emperor. In reality, this system of mutual control was not always used, and in several cases officials from the Imperial Academy of Medicine did not personally take part in the decocting process. Sometimes they just submitted the prescription via the official channels and asked the Imperial Dispensary to create the medicine according to a recipe. ${ }^{21}$

The Imperial Workshops specialized in manufacturing various household items and representational accoutrements of the palace 
Figure 8.2 Various patterns for medical tablets (dingzi yao 錠子藥)

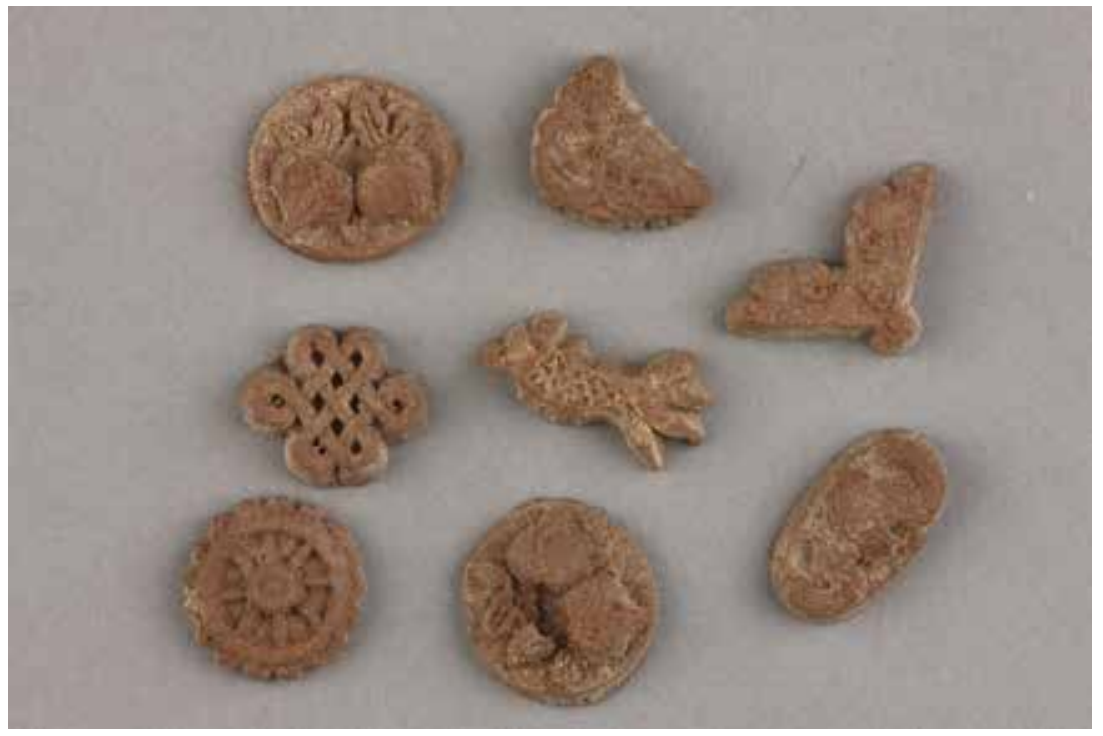

Source: The Palace Museum, Beijing

and imperial family under the management of the Imperial Household Department. The court archives show that, for a considerable period, the Imperial Workshops and the Imperial Dispensary shared responsibility for manufacturing medicines. The Imperial Workshops' main task in this was producing medical tablets (dingzi yao 錠子藥), which was undertaken by the Workshop for Producing Medicine (Zhiyao zuofang 製藥作坊; Figure 8.2 shows a selection of patterns used on these tablets), one of the many specialist workshops it supervised. Now and then other workshops were also involved.

The Imperial Dispensary was an institution that specialized in the manufacture of medicines and was stuffed full of experts such as doctors and their collaborating artisans. But this was not the case for the medicine-specific workshop in the Imperial Workshop. The archival documents show that the Imperial Workshop seems to have been a general manufactory which needed to borrow the necessary expertise from the Imperial Dispensary since it filed a document requesting doctors to be transferred into the workshop in order to accomplish their task every time they were assigned one. After the medicines had been manufactured, the doctors were transferred back to the Dispensary. Nevertheless, the emperor sometimes worried about the quality of medicines. When Emperor Qianlong once inquired about the manufacture of medicine at the Imperial Workshop, Shuwen 舒文, chief 
supervisor of the Imperial Household Department (Neiwufu dachen 内务 府大臣), replied:

Every year we follow the established prescription, summon doctors from the Imperial Dispensary to process, compound and manufacture the demanded medicines, and we assign an additional doctor and a vice director (yuanwailang 員外郎) to supervise the work... Since Your Majesty has today inquired about the processing and compounding of the medicines in the Imperial Workshops this year, your servant [I] will personally, together with the doctors, lead the personnel to work dedicatedly and meticulously in processing and compounding. ${ }^{22}$

This sentence suggests that in certain cases, when medicines were produced by workers who might lack expertise, or generally to prevent cheating and mistakes, two mid-level officers were assigned to monitor the manufacture and take responsibility if anything went wrong.

\section{Conclusion}

The supply chain of medicinal materials in the Qing imperial court was conceived as a fully integrated and flexible whole. As one of the many supply systems in other parts of the palace machine, it fed on diverse sources. The various specialized offices involved in procuring medicine for the court were integrated into a chain of actions, each office in charge of one stage of the supply chain - from collection and delivery, to reception and inspection, storage, manufacture, and the final stage of disposal. Responsibility for the medicinal materials and all other duties connected to them moved from stage to stage and actor to actor and thereby connected the different administrative spaces. Starting far from the court at the level of local prefectures, county governments and provincial administrative commissioners, the medicinals moved into the sphere of the central agencies at the heart of the Qing empire, such as the Board of Revenue, the Board of Rites and the Imperial Academy of Medicine, to eventually arrive in the palace under the administration of the Imperial Household Department, with its Imperial Dispensary and the Imperial Workshops. They all served to

22 Qing gong Neiwufu Zaobanchu dang'an zonghui 清宮內務府造辦處檔案總匯, ed. by Chinese University of Hong Kong and The First Historical Archives of China (Beijing: Renmin chubanshe, 2005), vol. 50, 28 . 
maintain the supply of medicinal materials to the court and for the bodies of the emperor and his family, performing their jobs in a linked chain of actions and responsibilities, thereby monitoring and coordinating with one another.

The flexibility of the system came to the fore when conflicts arose between the established regulations, precedents or conventions and the practical cases. In these cases expediency became the problem-solving principle. The quota of medical materials for each province did not remain static but changed year by year in terms of whether the tributes were collected in their original form, converted into cash, or as a mix of both. The rule of acquiring medicinal materials from special court purveyors for fixed prices and on a commission basis was moderated by issuing merchants advance payments and granting temporary adjustments of the price of medical materials, in line with market fluctuations.

The system dealt with medicinal materials of diversified origins, which included local tributes collected from each province, commodities purchased through commissioned merchants, and concoctions manufactured in the medical and artisanal workshops in court. It is noteworthy that the court did not perceive any inherent difference between raw materials - be they plants, animal parts, or minerals - and prepared consumables from its own dispensary or from Western countries. All were considered 'medicine', i.e. yao 藥.

Therefore, although the medicine supply system of the Qing court might at first glance appear to be simply a matter of the court procuring medicinal materials, in fact it involved multilayers of institutions, ranging from local governments as providers of raw materials and specialized regional products, to commercial houses trading in medicinals and concoctions, further on to state ministries and institutions at the court which not only controlled, produced, stored and re-sold medicines, to finally prescribe, produce and administer medicines to the emperor and his family. Although each institution held different positions in an extended network, they all served the shared duty of supplying medicines to the court. Each of them performed their own routine duties within the seeming self-sufficient palace machine (zizhuan 自轉), which were often unrelated to medicine, and interlocked and worked collaboratively with public actors (gongzhuan 公轉) when drawn into the supply chain of provisioning imperial health.

Although the processes involved many institutions and a large number of personnel, ultimately it was the emperor himself who controlled the system and made decisions on activities regarding collecting, purchasing, manufacturing, and disposing of medicines. While the respective agencies 
carried out the specific tasks, all the important issues were reported to the emperor, who was the final arbiter (and direct benefactor of the medicines). In other words, a chaine operatoire was established, extending out from the central court to the local fields, with the imperial body firmly at its centre. In the final analysis, the vast capacities and knowledge of both the political system of the empire and the manufacturing network of the medical institutions and artisanal workshops in the palace compounds, as well as commercial actors, were commandeered to guarantee a continuous supply of medicines for the court. The collaboration between those institutions in a regulated but responsive chain ensured the timely and adequate supply of the best medicine in the empire to enhance and secure the health of the emperor and his family.

Translated from Chinese by Yuanxie Shi

\section{About the Author}

XUELING GUAN 关雪玲 is a researcher (equivalent to curator) at the Palace Museum in Beijing. She specialises in the history of medicine of the Qing court on which she has published numerous articles and monographs such as Qingdaigongting yixue yuyixue wenwu 清代宮廷醫學與醫學文物 (The Court Medicine of the Qing Dynasty and Historical Medicinal Artifacts). 
